\title{
Predicting nutrient excretion from dairy cows on smallholder farms in Indonesia using readily available farm data
}

\author{
Windi Al Zahra ${ }^{1,2, *}$, Corina E. van Middelaar ${ }^{1}$, Imke J.M de Boer ${ }^{1}$, and Simon J. Oosting ${ }^{1}$
}

* Corresponding Author: Windi Al Zahra Tel: +31-621914236, Fax: +31-7483953,

E-mail: windi.alzahra@wur.nl

'Animal Production Systems Group, Wageningen University \& Research, P.O. Box 338, 6700 AH,

Wageningen, The Netherlands

2 Department of Animal Production and Technology,

Faculty of Animal Science, IPB University (Bogor

Agricultural University), Bogor, West Java 16680,

Indonesia

ORCID

Windi Al Zahra

https://orcid.org/0000-0002-5220-8976

Corina E. van Middelaar

https://orcid.org/0000-0002-6835-998X

Imke J.M de Boer

https://orcid.org/0000-0002-0675-7528

Simon J. Oosting

https://orcid.org/0000-0003-2080-1879

Submitted Feb 11, 2020; Revised Mar 17, 2020; Accepted Apr 23, 2020
Objective: This study was conducted to provide models to accurately predict nitrogen $(\mathrm{N})$ and phosphorus $(\mathrm{P})$ excretion of dairy cows on smallholder farms in Indonesia based on readily available farm data.

Methods: The generic model in this study is based on the principles of the Lucas equation, describing the relation between dry matter intake (DMI) and faecal $\mathrm{N}$ excretion to predict the quantity of faecal $\mathrm{N}\left(\mathrm{Q}_{\mathrm{FN}}\right)$. Excretion of urinary $\mathrm{N}$ and faecal $\mathrm{P}$ were calculated based on National Research Council recommendations for dairy cows. A farm survey was conducted to collect input parameters for the models. The data set was used to calibrate the model to predict $\mathrm{Q}_{\mathrm{FN}}$ for the specific case. The model was validated by comparing the predicted quantity of faecal $\mathrm{N}$ with the actual quantity of faecal $\mathrm{N}\left(\mathrm{Q}_{\mathrm{FNACT}}\right)$ based on measurements, and the calibrated model was compared to the Lucas equation. The models were used to predict $\mathrm{N}$ and $\mathrm{P}$ excretion of all 144 dairy cows in the data set.

Results: Our estimate of true $\mathrm{N}$ digestibility equalled the standard value of $92 \%$ in the original Lucas equation, whereas our estimate of metabolic faecal $\mathrm{N}$ was $-0.60 \mathrm{~g} / 100 \mathrm{~g}$ DMI, with the standard value being $-0.61 \mathrm{~g} / 100 \mathrm{~g}$ DMI. Results of the model validation showed that the $\mathrm{R}^{2}$ was 0.63 , the MAE was $15 \mathrm{~g} /$ animal/d ( $17 \%$ from $\mathrm{Q}_{\mathrm{FNACT}}$ ), and the RMSE was $20 \mathrm{~g} /$ animal/d ( $22 \%$ from $\left.\mathrm{Q}_{\mathrm{FNACT}}\right)$. We predicted that the total $\mathrm{N}$ excretion of dairy cows in Indonesia was on average $197 \mathrm{~g} / \mathrm{animal} / \mathrm{d}$, whereas $\mathrm{P}$ excretion was on average $56 \mathrm{~g} / \mathrm{animal} / \mathrm{d}$.

Conclusion: The proposed models can be used with reasonable accuracy to predict $\mathrm{N}$ and $P$ excretion of dairy cattle on smallholder farms in Indonesia, which can contribute to improving manure management and reduce environmental issues related to nutrient losses.

Keywords: Dairy Cows; N and P Excretion; Smallholder Dairy Farms

\section{INTRODUCTION}

The number of dairy cattle in Indonesia has increased from 503,000 in 2014 to 550,000 in 2018 due to an increase in the demand for milk and a governmental decision to support the growth of the national dairy sector [1]. This increase in dairy cattle, mainly kept on smallholder dairy farms, has enhanced the negative consequences associated with the lack of manure management on those farms, resulting in large amounts of discharged manure. Because dairy production in Indonesia is concentrated in regional clusters, this discharge of manure leads to high concentrations of nitrogen $(\mathrm{N})$ and phosphorus $(\mathrm{P})$ in local rivers and groundwater of densely populated areas, impacting human health and natural ecosystems [2]. Manure management on smallholder dairy farms must be improved to reduce those negative consequences.

Approximately $84 \%$ of the smallholder dairy farms in Indonesia discharge at least part of their manure into the environment [3]. While the urinary or liquid fraction is totally 
discharged, part of the solid fraction may be collected and sold to manure traders, crop or flower farmers, or used on the farm itself, i.e., as organic fertiliser or to produce biogas for cooking. In some cases, the solid manure fraction is composted before being sold or applied as fertiliser.

To improve manure management, information about $\mathrm{N}$ and $\mathrm{P}$ excretion of dairy cattle is needed. This information can be used to estimate nutrient losses from different manure treatment options and to quantify differences in nutrient use efficiency among farms and manure management systems. To accurately predict related environmental problems and losses of $\mathrm{N}$ and $\mathrm{P}$, the $\mathrm{N}$ and $\mathrm{P}$ excretion in faeces and urine should be calculated separately. This separation between faecal and urinary fraction is important, because these fractions are differently managed at the Indonesian dairy farms. Moreover, the nature of losses differs between both manure fractions: ammonia volatilization is much higher for the urinary than for the faecal fraction [4].

Quantifying N and P excretion from dairy cattle can be done by different methods, including actual measurements (e.g. in feeding trials) or by means of mathematical modelling. Both methods have advantages and drawbacks. Feeding trials are generally used to analyse the digestibility of individual feed ingredients and complete diets, providing an accurate estimate of $\mathrm{N}$ and $\mathrm{P}$ excretion [5]. This approach, however, is laborious, expensive, and difficult to scale to the level of a dairy farm. Mathematical modelling offers a method to predict $\mathrm{N}$ and $\mathrm{P}$ excretion using on-farm data, including animal and dietary characteristics [6-8]. A linear regression equation with dry matter intake (DMI) and crude protein (CP) intake was used to predict the $\mathrm{N}$ excretion of Chinese Holstein dairy cows [6]. Similarly, a linear function of DMI and $\mathrm{P}$ intake (PI) was used to estimate P excretion in high productivity lactating Holstein dairy cows [8].

Mathematical models may be useful to predict $\mathrm{N}$ and $\mathrm{P}$ excretion on dairy farms, but many of these models are developed based on input-output relationships that are applicable only to the specific condition under which the input-output model was assessed. Hence, such models may not be suitable for the Indonesian situation, because of differences not just regarding dietary composition and animal productivity, but also regarding, among others, environmental factors, breed, and production level which can have a substantial effect on the relation between feed intake and $\mathrm{N}$ and $\mathrm{P}$ excretion [9]. So far, a generic model to predict $\mathrm{N}$ and $\mathrm{P}$ excretion of dairy cows on smallholder farms in Indonesia is not available. Therefore, this study aims to provide models to accurately predict $\mathrm{N}$ and $\mathrm{P}$ excretion of dairy cows on smallholder farms in Indonesia based on readily available farm data. In this study, we calibrated and evaluated a generic model to predict faecal $\mathrm{N}$ excretion and we subsequently applied this model in combination with existing guidelines to predict $\mathrm{N}$ and $\mathrm{P}$ excretion in faeces and urine for 144 cows on 30 smallholder dairy farms in Indonesia.

\section{MATERIALS AND METHODS}

The generic model in this study is based on the principles of the Lucas equation, describing the relation between DMI and faecal $\mathrm{N}$ excretion [10-13]. In addition, we used the guidelines of the National Research Council (NRC) to calculate the daily $\mathrm{N}$ and $\mathrm{P}$ requirements of dairy cows [14], which were then used to calculate the excretion of urinary $\mathrm{N}$ and faecal $P$. The following section describes the model and guidelines. Subsequently, a description of the collection of farm data is provided, followed by a description of the calibration and evaluation of the faecal $\mathrm{N}$ model. Finally, we illustrate the reliability of the models by presenting the effective sample sizes required to identify a difference between treatments.

\section{Modelling N excretion}

The Lucas equation describes the apparent digestibility of nutrients, independent of the feed, based on true digestibility, and the endogenous loss of that nutrient in the faeces, (equation 1a) and is widely used in nutrient digestibility studies for ruminants, but most for protein and $\mathrm{N}$ [10-13]. The general Lucas equation for $\mathrm{N}$ is:

$$
\mathrm{DN}=\mathrm{m} \mathrm{TN}+\mathrm{b}
$$

where $\mathrm{DN}$ is the concentration of digestible nitrogen in ingested dry matter $(\mathrm{g} / 100 \mathrm{~g})$, TN is the concentration of total nitrogen in ingested dry matter $(\mathrm{g} / 100 \mathrm{~g})$, the slope $(\mathrm{m})$ is the true digestibility of the protein in the feed (fraction) and the intercept (b) is the concentration of endogenous $\mathrm{N}$ in ingested dry matter $(\mathrm{g} / 100 \mathrm{~g})$. If we multiply the left and righthand-side of equation (1a) with DMI (g/animal/d), we get equation $1 \mathrm{~b}$.

$$
\mathrm{DNI}=(\mathrm{m} \times \mathrm{TNI})+(\mathrm{b} \times \mathrm{DMI})
$$

where $\mathrm{DNI}$ is the digestible $\mathrm{N}$ intake (g/animal/d), and TNI is the total $\mathrm{N}$ intake (g/animal/d).

This reformulated Lucas equation enables prediction of the quantity of $\mathrm{N}$ in faeces $\left(\mathrm{Q}_{\mathrm{FN}}\right)$ (g/animal/d) since $\mathrm{Q}_{\mathrm{FN}}$ is the difference between total $\mathrm{N}$ intake (TNI) and digestible $\mathrm{N}$ intake (DNI), equation $2 \mathrm{a}$ :

$$
\mathrm{Q}_{\mathrm{FN}}=\mathrm{TNI}-\mathrm{DNI}
$$

Subsequently, we substitute DNI in equation (2a) by the reformulated Lucas equation (1b), yielding our equation to predict the quantity of faecal $\mathrm{N}$ given in equation $(2 \mathrm{~b}$ or $2 \mathrm{c}$ ): 


$$
\begin{aligned}
& \mathrm{Q}_{\mathrm{FN}}=\mathrm{TNI}-[(\mathrm{m} \times \mathrm{TNI})+(\mathrm{b} \times \mathrm{DMI})] \\
& \mathrm{Q}_{\mathrm{FN}}=[(1-\mathrm{m}) \times \mathrm{TNI}]-(\mathrm{b} \times \mathrm{DMI})
\end{aligned}
$$

The quantity of urinary $\mathrm{N}\left(\mathrm{Q}_{\mathrm{UN}}\right)(\mathrm{g} / \mathrm{animal} / \mathrm{d})$ can subsequently be calculated by subtracting total $\mathrm{N}$ retained $\left(\mathrm{N}_{\text {Ret }}\right)$ (g/animal/d) for producing milk, pregnancy, growth and scruf protein, and $\mathrm{Q}_{\mathrm{FN}}(\mathrm{g} /$ animal/d) from the total $\mathrm{N}$ intake (TNI) (g/animal/d), given in equation 3.

$$
\mathrm{Q}_{\mathrm{UN}}=\mathrm{TNI}-\mathrm{N}_{\mathrm{Ret}}-\mathrm{Q}_{\mathrm{FN}}
$$

Subsequently, the quantity of total $\mathrm{N}$ in manure $\left(\mathrm{Q}_{\mathrm{TN}}\right)(\mathrm{g} /$ animal/d) is calculated as the sum of $\mathrm{Q}_{\mathrm{FN}}(\mathrm{g} / \mathrm{animal} / \mathrm{d})$ and $\mathrm{Q}_{\mathrm{UN}}(\mathrm{g} / \mathrm{animal} / \mathrm{d})$, given in equation 4.

$$
\mathrm{Q}_{\mathrm{TN}}=\mathrm{Q}_{\mathrm{FN}}+\mathrm{Q}_{\mathrm{UN}}
$$

The $\mathrm{N}_{\text {Ret }}$ (g/animal/d) can be calculated for lactating, dry cows and young cows based on the NRC guidelines [14]. The scurf protein consists of protein loss from skin, skin secretions, and hair, and is calculated as $0.3 \times \mathrm{BW}^{0.60}$ (live weight). The retained $\mathrm{N}$ for milk production equals $\mathrm{N}$ in milk $\left(\mathrm{N}_{\text {Milk }}\right)$ (g/animal/d) and is calculated by multiplying the daily milk production (g/animal/d) with the protein concentration of milk, divided by 6.38 which is the conversion factor from milk protein to $\mathrm{N}$. The retained $\mathrm{N}$ for foetal growth in a pregnant animal $\left(\mathrm{N}_{\text {Preg }} ; \mathrm{g} / \mathrm{animal} / \mathrm{d}\right)$ is calculated by dividing the metabolizable protein requirement for pregnancy $\left(\mathrm{MP}_{\text {Preg }}\right)$ by 6.25. For cows between 190 to 279 days of pregnancy, $\mathrm{MP}_{\text {Preg }}$ is computed as:

$$
\begin{aligned}
\mathrm{MP}_{\text {Preg }}=[ & (0.69 \times \text { days in pregnancy }) \\
& -69.2 \times(\mathrm{CBW} / 45)] / \mathrm{Eff}_{\mathrm{MPreg}}
\end{aligned}
$$

where, CBW is calf birth weight $(\mathrm{kg})$, and $\mathrm{Eff}_{\mathrm{MPPreg}}$ is the efficiency of use of metabolised protein (MP) for pregnancy, which is assumed to be 0.33 .

For our model we assume that $\mathrm{N}$ retained for growth $\left(\mathrm{N}_{\text {Growth }}\right)$ of lactating and dry cows is zero. In young cows, $\mathrm{N}_{\text {Growth }}$ (g/animal/d) is estimated by dividing the metabolizable protein for growth $\left(\mathrm{MP}_{\text {Growth }}\right)$ by 6.25. The $\mathrm{MP}_{\text {Growth }}$ is computed based on equation 6 :

$$
\mathrm{MP}_{\text {Growth }}=\mathrm{NP}_{\mathrm{g}} /(0.834-(\mathrm{EQSBW} \times 0.00114)
$$

where $\mathrm{NP}_{\mathrm{g}}$ is net protein for gain and is calculated from SWGX (268-[29.4×(RE/SWG)]). SWG is the shrunk weight gain and is assumed to equal $13.9 \times \mathrm{NE}_{\text {Growthdiet }}^{0.9116} \times \mathrm{EQSBW}^{-0.6837}$. $\mathrm{NE}_{\text {Growthdiet }}$ is the net energy requirement for growth available $(\mathrm{Mcal} / \mathrm{d})$ and calculated as $\left(0.84 \mathrm{BW}^{0.355} \times \mathrm{WG}^{1.2}\right) \times 0.69$. BW is the current live weight of an animal $(\mathrm{kg})$ and $W G$ is the weight gain per animal (g/d). EQSBW is the equivalent shrunk body weight and is calculated as SBW $\times(478 / \mathrm{MSBW})$. SBW is shrunk body weight (animal weight after an overnight fast without feed or water) and being set at $96 \%$ of the current live weight. MSBW is the mature shrunk body weight and being set at $96 \%$ of the expected mature live weight (MW). The retained NE (RE) $(\mathrm{Mcal} / \mathrm{d})$ is assumed to equal $0.0635 \times$ EQEBW $^{0.75} \times$ EQEBG $^{1.097}$. EQEBW is equivalent empty body weight (weight without ingesta), and assumed to equal 0.891× EQSBW. EQEBG is the equivalent empty body weight gain, being calculated as $0.956 \times$ SWG.

\section{Modelling P excretion}

Unlike $\mathrm{N}$ that is in faeces and urine, $\mathrm{P}$ is mainly in faeces. The $\mathrm{P}$ that is contained in urine of dairy cows is minimal and, therefore, can be neglected [14-16]. The daily quantity of $\mathrm{P}$ excreted via faeces $\left(\mathrm{Q}_{\mathrm{FP}} ; \mathrm{g} / \mathrm{animal} / \mathrm{d}\right)$ is calculated as the differences between daily PI (g/animal/d) and P retained $\left(\mathrm{P}_{\text {Rei }}\right.$; $\mathrm{g} /$ animal/d) for milk production, pregnancy, and growth per day (equation 7). To calculate PI (g/animal/d), information about DMI (g/animal/d) and P concentration of the ingested $\mathrm{DM}(\mathrm{g} / \mathrm{kg})$ is required (equation 8).

$$
\begin{aligned}
& \mathrm{Q}_{\mathrm{FP}}=\mathrm{PI}-\mathrm{P}_{\text {Ret }} \\
& \mathrm{PI}=\mathrm{DMI} \times \mathrm{P} \text { concentration of ingested } \mathrm{DM}
\end{aligned}
$$

The retained $\mathrm{P}$ for milk production equals $\mathrm{P}$ in milk $\left(\mathrm{P}_{\text {Milk; }}\right.$; $\mathrm{g} / \mathrm{animal} / \mathrm{d}$ ) and is calculated by multiplying the daily milk production $(\mathrm{kg} / \mathrm{animal} / \mathrm{d})$ with the $\mathrm{P}$ concentration of milk $(\mathrm{g} / \mathrm{kg})$. $\mathrm{P}$ retention for pregnancy $\left(\mathrm{P}_{\mathrm{Preg}} ; \mathrm{g} / \mathrm{animal} / \mathrm{d}\right)$ is calculated for cows in 190 to 279 days pregnancy based on equation 9:

$$
\mathrm{P}_{\text {Preg }}=0.02743 \mathrm{e}^{(0.05527-0.000075 \mathrm{t}) \mathrm{t}}-0.02743 \mathrm{e}^{(0.05527-0.000075(\mathrm{t}-1))(\mathrm{t}-1)}
$$

where $t$ is day of gestation.

The retained $\mathrm{P}$ for growth $\left(\mathrm{P}_{\text {Growth }}\right)$ of lactating and dry dairy cows is assumed to be zero. In young cows, $P$ retention for growth $\left(\mathrm{P}_{\text {Growth }} ; \mathrm{g} / \mathrm{animal} / \mathrm{d}\right)$ is estimated based on equation 10:

$$
\mathrm{P}_{\text {Growth }}=\left[1.2+\left(4.635 \times \mathrm{MW}^{0.22}\right) \times\left(\mathrm{BW}^{0.22}\right)\right] \times(\mathrm{WG} / 0.96)
$$

where the MW is the estimated expected mature live weight per animal $(\mathrm{kg}), \mathrm{BW}$ is current live weight per animal $(\mathrm{kg})$, and $W G$ is the weight gain per animal $(\mathrm{g} / \mathrm{d})$.

\section{Data collection}

A farm survey was conducted to collect data for model calibra- 
tion to predict $\mathrm{N}$ and $\mathrm{P}$ excretion of dairy cows in Indonesian smallholder farms. The survey was conducted in December 2017 in the Lembang district, West Java, Indonesia. This district is known as one of the largest clusters of smallholder dairy farms in Indonesia. We selected 30 out of the 300 dairy farms which participated in a baseline survey conducted within the project Sustainable Intensification Dairy Production in Indonesia [3]. The district has approximately 5,000 dairy farms. The selection of the 30 farms was purposively done to include four distinct manure management systems. However, the difference in manure management systems is not relevant for this paper, and, therefore, will not be discussed here. All farmers were members of a dairy cooperative in Lembang, West Java.

The input parameters to calibrate and evaluate the models to predict $\mathrm{N}$ and $\mathrm{P}$ excretion were the animal's diet and production stage including herd composition (lactating, dry, and young cows), daily milk yield, manure composition and the live weight of the animals (Table 1). The number of days in pregnancy for dry cows was provided by the farmers during the interview (range from 210 to 240 days). The live weight (BW) of each cow was estimated based on the hearth girth using the Schoorl equation [19]. Information about calf birth weight (CBW), expected mature live weight (MW) and weight gain (WG) was not available from the survey and, therefore, was estimated based on literature representing the Indonesian situation. CBW per animal was assumed to be $40 \mathrm{~kg}$ [20], MW per animal was assumed as $500 \mathrm{~kg}$, and WG per animal was assumed to equal $450 \mathrm{~g} / \mathrm{d}$ [21].

The feed for the animals was offered three times daily (i.e., in the morning, at noon and in the afternoon) and the quantity of offered feed ( $\mathrm{g} / \mathrm{animal} / \mathrm{d}$ ) was measured at each feeding time using a weighing scale. The net individual diet on fresh weight basis (g/animal/d) was determined based on the difference between feed offered and feed left-over with the latter being collected the day after before the first feeding time. The feed leftover comprised the roughages only. At each farm we collected feed samples of all feeds offered such as roughages, compound feed, and agro-industrial by-products. Dry matter (DM), ash, CP, and P concentration of each feed product of each farm were measured in the laboratory.

During the farm survey, from each lactating cow we measured daily milk production (g/animal/d) using a weighing scale and we collected a milk sample twice a day during milking time (morning and afternoon). Each milk sample was analysed for $\mathrm{N}$ and $\mathrm{P}$ concentration $(\mathrm{g} / \mathrm{kg})$. Furthermore, a sample of fresh faeces was collected from each farm for analysis of DM, N, and P concentration $(\mathrm{g} / \mathrm{kg})$.

The laboratory analysis of DM concentration of the feed samples was determined by drying at $105^{\circ} \mathrm{C}$ until constant

Table 1. Input parameters to calibrate and evaluate the models to predict nitrogen $(\mathrm{N})$ and phosphorus $(\mathrm{P})$ excretion on smallholder dairy farms

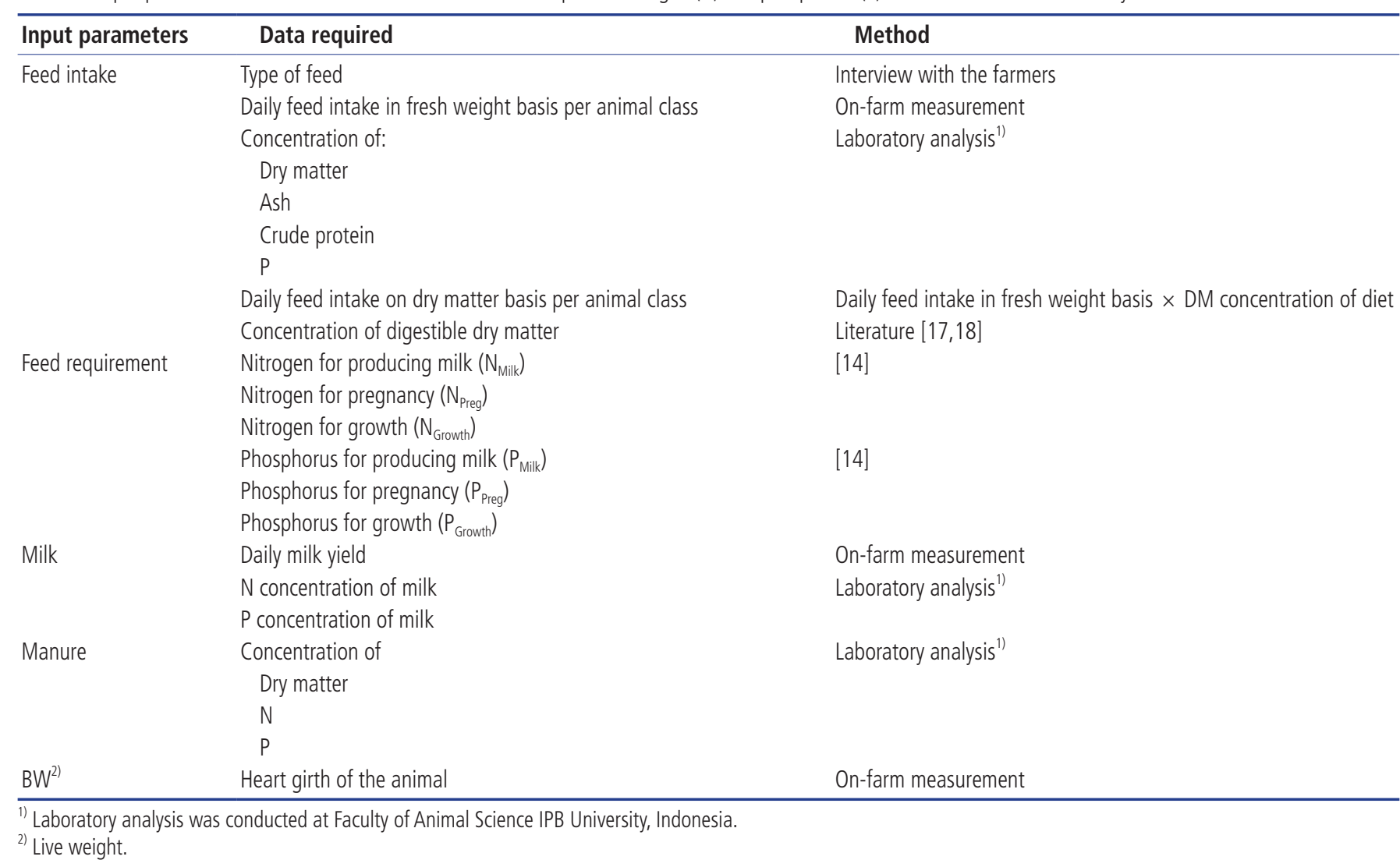


weight and ash was determined by ashing at $600^{\circ} \mathrm{C}$. We assumed that the nutritional composition of feeds was similar for offered feed and feed left-overs. The DM concentration of the fresh faeces was determined in a $105^{\circ} \mathrm{C}$ drying process. The $\mathrm{N}$ analysis was done by using the standard Kjeldahl method. The $\mathrm{N}$ value was multiplied by 6.25 for feed and faeces, and by 6.38 for milk to determine the protein concentration. The $\mathrm{P}$ concentration was analysed using a titrimetric method for the feed sample and a microcolorimetric method for the milk and faeces sample. The laboratory analysis of feed, milk, and faeces was conducted in the Faculty of Animal Science, IPB University, Indonesia.

\section{Model calibration and evaluation}

The farm data were used to calibrate and evaluate the $\mathrm{Q}_{\mathrm{FN}}$ model. To calibrate the $\mathrm{Q}_{\mathrm{FN}}$ model for the Indonesian context, the data set was divided into a training data set $(3 / 5$ of the total data set) and a testing data set (the remaining 2/5). The training data set was used to estimate the intercept and the slope of equation (1a) (Table 2). The testing data set was used for model evaluation. The training and testing data were randomly selected.

As the first step of model evaluation, we predicted the quantity of $\mathrm{N}$ in the faeces $\left(\mathrm{Q}_{\mathrm{FNPRED}}\right.$; $\left.\mathrm{g} / \mathrm{animal} / \mathrm{d}\right)$ using equation (2c). Following this, we compared the values of $\mathrm{Q}_{\mathrm{FNPRED}}$ with the actual measurement of faecal $\mathrm{N}$ from the independent data set $\left(\mathrm{Q}_{\mathrm{FNACT}} ; \mathrm{g} / \mathrm{animal} / \mathrm{d}\right)$. The $\mathrm{Q}_{\mathrm{FNACT}}$ values were calculated by multiplying the values of indigestible DMI (IDMI; g/animal/d) (Table 2) with the $\mathrm{N}$ concentration in faeces $(\mathrm{g} / \mathrm{kg})$ that was obtained from the laboratory analysis (Table 1). Finally, the proposed $\mathrm{Q}_{\mathrm{FNPRED}}$ model was statistically evaluated against the $\mathrm{Q}_{\mathrm{FNACT}}$ by using the mean average error (MAE) in equation [11] and the root mean square error (RMSE) in equation [12]. Both RMSE and MAE were presented as absolute and as relative value. The mean square error (MSE) consists of the bias error, the slope error, and the random error [22]. A low score of MAE and RMSE indicates a better model performance.

$$
\text { MAE }=\frac{1}{n} \sum_{i=1}^{n}\left(X_{\text {observation }}-X_{\text {prediction }}\right)
$$

$$
\mathrm{RMSE}=\sqrt{\frac{1}{n} \sum_{i=1}^{n}\left(X_{\text {observation }}-X_{\text {prediction }}\right)^{2}}
$$

In addition, the predicted intercept and slope of $\mathrm{Q}_{\mathrm{FN}}$ model for smallholder dairy farms $\left(\mathrm{Q}_{\mathrm{FNPRED}}\right)$ were compared to the intercept and slope reported for the Lucas equation for $\mathrm{N}$ in literature [12]. The literature values for intercept and slope of the Lucas equation for $\mathrm{N}$ are $92 \%$ and $-0.61 \mathrm{~g} \mathrm{~N} / 100 \mathrm{~g}$ DMI, respectively.

\section{Effective sample size}

The accuracy of a model determines the effective sample size (i.e. the number of dairy cows required) in a study to detect a specific difference between two treatments (e.g., before and after an intervention) [23]. A larger sample size is needed when a less accurate model is used. The accuracy of a model is expressed by the reliability score which is equal to the coefficient of determination $\left(R^{2}\right)$ of the model. In this study, the $\mathrm{R}^{2}$ was the $\mathrm{R}^{2}$ from the regression of $\mathrm{Q}_{\mathrm{FNPRED}}$ on $\mathrm{Q}_{\mathrm{FNACT}}$. The $\mathrm{R}^{2}$ from the actual measurement of faecal $\mathrm{N}\left(\mathrm{Q}_{\mathrm{FNACT}}\right)$ was assumed as without error $\left(R^{2}=1\right)$. The Cohen method [23] was used to determine the effective sample size for $\mathrm{Q}_{\mathrm{FNPRED}}$ and $\mathrm{Q}_{\mathrm{FNACT}}$ (equation 13):

$$
n=\frac{2 \delta^{2}}{(d)^{2}}
$$

where, $n$ is the effective sample size and $\delta$ is the critical value of $t$, and the $t$ is the critical $t$-value in the t-test distribution given as $t_{1-\alpha}$ and $t_{1-\beta}$. The $\delta$ is calculated as $\delta=\left(t_{1-\alpha}-t_{1-\beta}\right)$. The $\alpha$ indicates the probability of a type I error and $\beta$ the probability of a type II error. The $d$ is the standardized effect size and calculated as $\left(m_{A}-m_{B} / \sigma\right)$ where $m_{A}$ and $m_{B}$ are the means of populations $\mathrm{A}$ and $\mathrm{B}$, respectively (e.g. with and without an intervention), and $\sigma$ is the population standard deviation. The two populations ( $\mathrm{A}$ and $\mathrm{B}$ ) were assumed to have equal variances and an equal reliability coefficient, $\alpha$ was set at $\mathrm{p}=0.05$ (one-tailed), and $\beta$ at $\mathrm{p}=0.20$. In this study, we calculated the effective sample sizes in order to detect a specific differ-

\begin{tabular}{|c|c|}
\hline Parameters & Equations \\
\hline DMI (g/animal/d) & The net daily feed intake in fresh weight basis $(\mathrm{g} /$ animal $/ \mathrm{d}) \times$ DM concentration $(\mathrm{g} / \mathrm{kg})$ \\
\hline DDMI (g/animal/d) & $\mathrm{DMI}(\mathrm{g} / \mathrm{animal} / \mathrm{d}) \times \mathrm{DDM}$ concentration $(\mathrm{g} / \mathrm{kg})$ \\
\hline TNI (g/animal/d) & DMI (g/animal/d) $\times$ CP concentration in feed $/ 6.25(\mathrm{~g} / \mathrm{kg})$ \\
\hline IDNI or $Q_{\text {FNACT }}(g / a n i m a l / d)$ & IDMI $(\mathrm{g} /$ animal $/ \mathrm{d}) \times \mathrm{N}$ concentration in the faeces $(\mathrm{g} / \mathrm{kg})$ \\
\hline DNI (g/animal/d) & $\mathrm{NI}$ (g/animal/d) - IDN (g/animal/d) \\
\hline
\end{tabular}
ence of $\mathrm{Q}_{\mathrm{FN}}$ ranging from 1 to $30 \mathrm{~g} / \mathrm{animal} / \mathrm{d}$. All statistical

Table 2. Parameters and equations to calibrate and evaluate the $Q_{\mathrm{FN}}$ model

$\mathrm{Q}_{\mathrm{FN}}$ quantity of faecal N; DMI, dry matter intake; DM, dry matter; DDM, digestible dry matter; DDMI, digestible dry matter intake; IDMI, indigestible dry matter intake; TNI, total nitrogen intake; CP, crude protein; IDNI, indigestible nitrogen intake; $\mathrm{Q}_{\mathrm{FNACT}}$ actual quantity of faecal N; DNI, digestible nitrogen intake; NI, nitrogen intake; IDN, indigestible nitrogen intake. 
analyses in the present study were performed in $\mathrm{R}$ ( $\mathrm{R}$ Core Team, 2018).

\section{RESULTS}

\section{Farm survey findings}

The 30 smallholder dairy farmers in this study kept a total of 144 dairy cows, i.e. 106 lactating cows, 12 dry cows, and 26 young cows. The young cows counted 12 replacement females with an average age between 6 to 24 months, and 14 calves (males and females) with an average age between 4 and 5 months. Lactating cows had an average live weight of $433 \mathrm{~kg}$, and an average milk yield of $13 \mathrm{~kg}$ per day. Dry cows had an average live weight of $419 \mathrm{~kg}$ and were 210 to 240 days in pregnancy. Young cows had an average live weight of 278 $\mathrm{kg}$. Table 3 provides an overview of the feed types and the average feed intake per animal class. There was no difference between the type of feed fed to lactating cows, dry cows, and young cows. Overall, on a DM basis, the diet of lactating cows, dry cows and young calves, but at different intake levels, consisted of roughages such as elephant grass, road side grass, and rice straw (48\%), agro-industrial by-products, such as tofu waste and cassava waste (22\%), and concentrates (28\%). Relatively low amounts of other feed products such as legumes (0.3\%), premix (0.01\%), banana stalks $(0.09 \%)$, and crop leftovers $(0.6 \%)$ were fed. These products were excluded from the model since the amount was insignificant, and the usage was inconsistent across farms.

Table 4 shows the average nutrient composition of feed, milk and faeces. The average CP concentration of $140 \mathrm{~g} / \mathrm{kg}$ $\mathrm{DM}$ in concentrate feed was at the lower range of $\mathrm{CP}$ levels in concentrates for dairy cattle generally used in Indonesia (140 to $210 \mathrm{~g} / \mathrm{kg} \mathrm{DM}$ ) [24]. The average protein concentration of $34 \mathrm{~g} / \mathrm{kg}$ for milk met the minimum Indonesian requirement of $27 \mathrm{~g} / \mathrm{kg}$ milk [25]. The average $\mathrm{N}$ concentration of $24 \mathrm{~g} / \mathrm{kg}$ DM for the faeces was within the range of 22 to 26
Table 3. An overview of the feed types and the average of feed intake (mean \pm standard error) by lactating, dry and young cows on a dry matter basis (g/ animal/d) on 30 smallholder dairy farms in the Lembang, West Java, Indonesia

\begin{tabular}{lrcr}
\hline Feed type & Lactating cows & \multicolumn{1}{c}{ Dry cows } & \multicolumn{1}{c}{ Young cows } \\
\hline Elephant grass & $3,620 \pm 284$ & $4,319 \pm 1,130$ & $3,310 \pm 744$ \\
Road side grass & $1,342 \pm 293$ & $752 \pm 656$ & $571 \pm 396$ \\
Rice straw & $949 \pm 137$ & $515 \pm 276$ & $485 \pm 251$ \\
Cassava waste & $1,230 \pm 151$ & $713 \pm 253$ & $295 \pm 159$ \\
Tofu waste & $1,944 \pm 211$ & $1,881 \pm 496$ & $1,049 \pm 258$ \\
Concentrate & $4,796 \pm 351$ & $2,590 \pm 940$ & $1,763 \pm 453$ \\
Total & $13,881 \pm 632$ & $10,769 \pm 603$ & $7,472 \pm 466$ \\
\hline
\end{tabular}

$\mathrm{g} / \mathrm{kg} \mathrm{DM}$ as found in literature [26,27] and the P concentration of $7 \mathrm{~g} / \mathrm{kg} \mathrm{DM}$ for the faeces was in the range of 5.2 to 7.4 $\mathrm{g} / \mathrm{kg} \mathrm{DM}$ as found in literature [28].

Table 5 presents the feed intake per animal class. Results show that the quantity of feed differed among animal classes. Intake of DM, N, and $\mathrm{P}$ were higher in lactating cows than in dry cows, which in turn had higher intake of these nutrients than young stock. On average, lactating cows consumed $22 \%$ more than dry cows, and $46 \%$ more than young cows. Similarly, on average, the NI was $25 \%$ higher in lactating cows compared to dry cows and $48 \%$ higher compared to young cows. The average PI was $27 \%$ higher in lactating dairy cows compared to dry cows and $48 \%$ higher compared to young cows.

\section{Model calibration and evaluation}

The training data set $(n=86)$ was used to estimate the intercept and the slope for equation (1a). The intercept was found to be $-0.60 \mathrm{~g} / 100 \mathrm{~g}$ DMI and the slope was found to be 0.92 . This implies that the amount of metabolic faecal $\mathrm{N}$ increases by $0.6 \mathrm{~g}$ per $100 \mathrm{~g}$ DMI with a predicted true digestibility of the protein in the feed of $92 \%$. The proposed $\mathrm{Q}_{\mathrm{FN}}$ model for Indonesian smallholder dairy farms is therefore:

Table 4. Average nutrient composition of feed, milk, and faeces samples collected (mean \pm standard error)

\begin{tabular}{|c|c|c|c|c|c|c|}
\hline Feed type & $n^{1)}$ & DM & $\mathrm{CP}$ & $\mathbf{P}$ & Ash & DDM \\
\hline \multicolumn{7}{|l|}{ Nutrients composition of feed ( $\mathrm{g} / \mathrm{kg} \mathrm{DM}$ ) } \\
\hline Elephant grass & 27 & $178 \pm 11$ & $101 \pm 6$ & $4 \pm 0.1$ & $112 \pm 6$ & $529[17]$ \\
\hline Road side & 9 & $188 \pm 15$ & $103 \pm 7$ & $5 \pm 0.4$ & $101 \pm 9$ & 489 [18] \\
\hline Rice straw & 11 & $319 \pm 32$ & $90 \pm 3$ & $3 \pm 0.3$ & $198 \pm 13$ & 408 [17] \\
\hline Tofu waste & 15 & $155 \pm 7$ & $201 \pm 2$ & $3 \pm 0.2$ & $33 \pm 2$ & $865[18]$ \\
\hline Cassava waste & 17 & $181 \pm 13$ & $61 \pm 5$ & $4 \pm 0.5$ & $28 \pm 10$ & 768 [17] \\
\hline \multirow[t]{2}{*}{ Concentrate } & 30 & $876 \pm 3$ & $140 \pm 1$ & $7 \pm 0.4$ & $73 \pm 3$ & $861[17]$ \\
\hline & $n^{1)}$ & & \multicolumn{2}{|c|}{ Protein } & \multicolumn{2}{|c|}{$\mathbf{P}$} \\
\hline \multirow[t]{2}{*}{ Nutrient composition of milk (g/kg) } & 106 & & \multicolumn{2}{|c|}{$34 \pm 0.4$} & \multicolumn{2}{|c|}{$0.6 \pm 0.005$} \\
\hline & $\mathrm{n}^{1)}$ & DM & \multicolumn{2}{|c|}{$\mathrm{N}$ total } & \multicolumn{2}{|c|}{$\mathbf{P}$} \\
\hline Nutrient composition of faeces (g/kg DM) & 30 & $138 \pm 10$ & \multicolumn{2}{|c|}{$24 \pm 0.5$} & \multicolumn{2}{|c|}{$7.0 \pm 0.2$} \\
\hline
\end{tabular}

$\mathrm{DM}$, dry matter; $\mathrm{CP}$, crude protein; $\mathrm{P}$, phosphorus; DDM, dry matter digestibility; $\mathrm{N}$, nitrogen.

1) Number of sample. 
Table 5. Feed intake on a dry matter basis per animal class ( $\mathrm{g} / \mathrm{animal} / \mathrm{d}$ ) used to calibrate and evaluate $\mathrm{N}$ and $\mathrm{P}$ excretion model

\begin{tabular}{|c|c|c|c|}
\hline Parameters & Minimum & Maximum & Mean \pm SE \\
\hline \multicolumn{4}{|c|}{ Lactating dairy cows ( $n=106$ ) } \\
\hline DMI & 6,548 & 22,048 & $13,881 \pm 632$ \\
\hline DDMI & 4,706 & 16,159 & $9,738 \pm 232$ \\
\hline IDMI & 1,815 & 7,370 & $4,142 \pm 114$ \\
\hline $\mathrm{CPI}$ & 859 & 3,214 & $1,756 \pm 49$ \\
\hline $\mathrm{NI}$ & 138 & 514 & $281 \pm 8$ \\
\hline IDN & 42 & 273 & $101 \pm 4$ \\
\hline DN & 67 & 319 & $180 \pm 5$ \\
\hline $\mathrm{PI}$ & 26 & 141 & $71 \pm 3$ \\
\hline \multicolumn{4}{|c|}{ Dry dairy cows $(n=12)$} \\
\hline $\mathrm{DMl}$ & 5,615 & 19,476 & $10,769 \pm 603$ \\
\hline DDMI & 4,611 & 13,215 & $7,300 \pm 700$ \\
\hline IDMI & 833 & 6,261 & $3,500 \pm 500$ \\
\hline CPI & 798 & 2,166 & $1,320 \pm 111$ \\
\hline $\mathrm{NI}$ & 128 & 346 & $211 \pm 18$ \\
\hline IDN & 24 & 130 & $84 \pm 8$ \\
\hline DN & 43 & 228 & $127 \pm 16$ \\
\hline $\mathrm{PI}$ & 26 & 125 & $52 \pm 8$ \\
\hline \multicolumn{4}{|c|}{ Young dairy cows $(n=26)$} \\
\hline DMl & 3,403 & 15,548 & $7,472 \pm 466$ \\
\hline DDMI & 2,624 & 10,400 & $4,853 \pm 398$ \\
\hline IDMI & 589 & 5,147 & $2,578 \pm 198$ \\
\hline CPI & 654 & 1,886 & $918 \pm 69$ \\
\hline $\mathrm{NI}$ & 51 & 302 & $147 \pm 11$ \\
\hline IDN & 38 & 144 & $63 \pm 6$ \\
\hline DN & 32 & 190 & $84 \pm 8$ \\
\hline $\mathrm{Pl}$ & 15 & 102 & $37 \pm 4$ \\
\hline
\end{tabular}

SE, standard error; DMI, dry matter intake; DDMI, digestible dry matter intake; IDMI, indigestible dry matter intake; $\mathrm{CPI}$, crude protein intake; $\mathrm{NI}$, nitrogen intake; IDN, indigestible nitrogen intake; DN, digestible nitrogen intake; PI, phosphorous intake.

$$
\begin{aligned}
\mathrm{Q}_{\mathrm{FN}}(\mathrm{g} / \mathrm{animal} / \mathrm{d})= & {[0.08 \times \mathrm{TNI}(\mathrm{g} / \mathrm{animal} / \mathrm{d})} \\
& +0.60 \times \mathrm{DMI}(100 \mathrm{~g} / \mathrm{animal} / \mathrm{d})](\text { eq. } 14)
\end{aligned}
$$

The testing data set $(\mathrm{n}=58)$ was subsequently used to evaluate the $\mathrm{Q}_{\mathrm{FN}}$ model in equation 14, by comparing $\mathrm{Q}_{\mathrm{FNPRED}}$ with $\mathrm{Q}_{\mathrm{FNACT}}$ (Figure 1). The coefficient of determination $\left(\mathrm{R}^{2}\right)$ of $\mathrm{Q}_{\mathrm{FNPRED}}$ and $\mathrm{Q}_{\mathrm{FNACT}}$ was 0.63 (residual standard error = 17.6, $\mathrm{p}<0.05)$. In this regression line, the intercept was significantly different from zero $(\mathrm{p}=0.0003)$, however, the slope did not significantly differ from one $(p=0.16)$. The MAE was $15 \mathrm{~g} /$ animal/d which translates to $17 \%$ deviation of $\mathrm{Q}_{\mathrm{FNPRED}}$ from the $\mathrm{Q}_{\mathrm{FNACT}}$. The RMSE was $20 \mathrm{~g} / \mathrm{animal} / \mathrm{d}$ which translates to $22 \%$ deviation of $\mathrm{Q}_{\mathrm{FNPRED}}$ from the $\mathrm{Q}_{\mathrm{FNACT}}$. The bias error of the MSE was 9\%, the slope error was $12 \%$ and the random error was $79 \%$. The slope and intercept which we estimated for equation $2 \mathrm{c}$ were similar to those reported in literature [12].

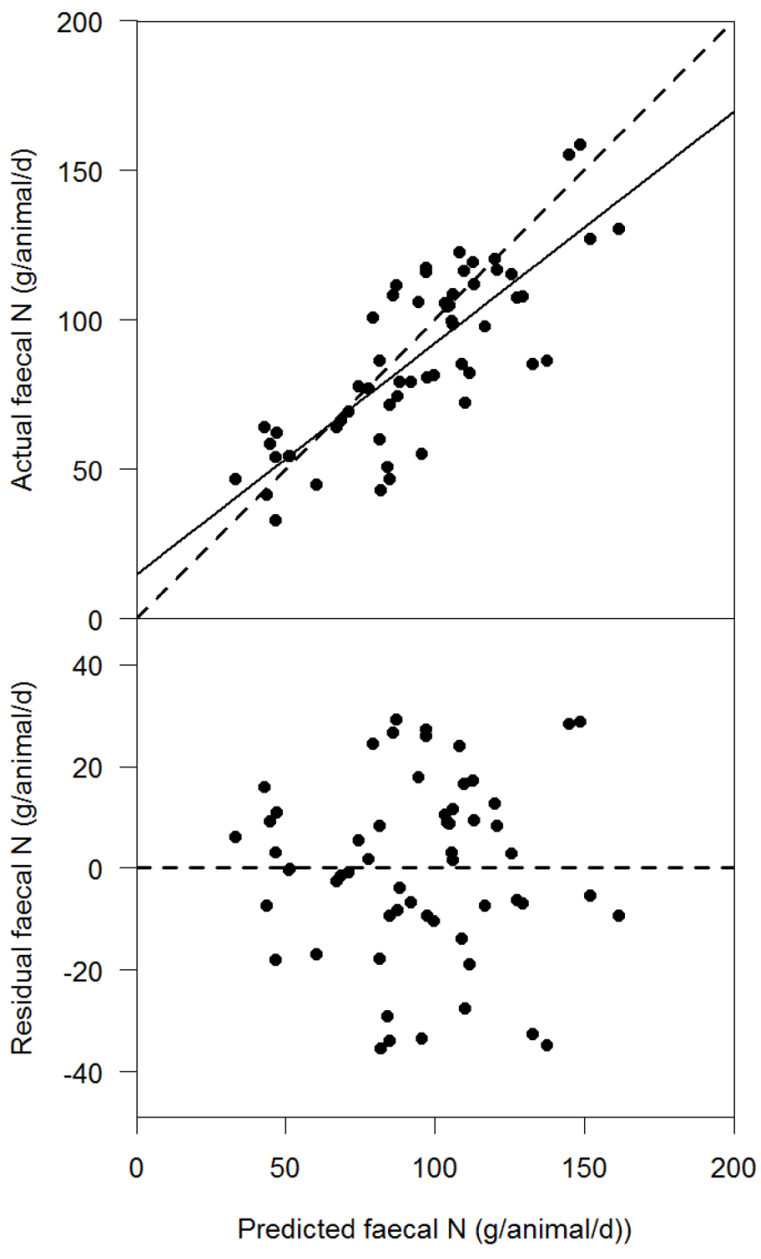

Figure 1. Plot of model evaluation of $\mathrm{Q}_{\mathrm{FN}}$ for the data set. The solid line indicates the regression line of prediction faecal $N\left(Q_{\text {FNPRED }}\right)$ and actual faecal $N$ $\left(Q_{\text {FNACT }}\right)$. The dashed line is the line of unity. $Q_{\text {FN }}$ quantity of faecal $N ; Q_{\text {FNPRED }}$ predicted quantity of faecal $\mathrm{N} ; \mathrm{Q}_{\mathrm{FNACT}}$ actual quantity of faecal $\mathrm{N}$.

\section{Effective sample size}

The effective sample size i.e. the number of dairy cows required in an experimental treatment to detect a specific difference between $\mathrm{Q}_{\mathrm{FN}}$ of different treatments was compared between $\mathrm{Q}_{\mathrm{FNPRED}}$ (i.e., derived from equation (14)) and $\mathrm{Q}_{\mathrm{FNACT}}$ (i.e., derived from measurements). The relationship between effective sample size of dairy cows (n) and a specific difference of $\mathrm{Q}_{\mathrm{FN}}(\mathrm{g} / \mathrm{animal} / \mathrm{d})$ in two alternative models $\left(\mathrm{Q}_{\mathrm{FNPRED}} ; \mathrm{R}^{2}=0.63\right.$ and $\left.\mathrm{Q}_{\mathrm{FNACT}} ; \mathrm{R}^{2}=1\right)$ is illustrated in Figure 2. To detect a specific difference in $\mathrm{Q}_{\mathrm{FN}}$ of $10 \mathrm{~g} / \mathrm{ani}$ $\mathrm{mal} / \mathrm{d}$, for example, requires 68 animals when using $\mathrm{Q}_{\mathrm{FNACT}}$, while 107 animals are needed when using $\mathrm{Q}_{\mathrm{FNPRED}}$. For specific differences higher than $20 \mathrm{~g} / \mathrm{animal} / \mathrm{d}$ the effective sample size did not differ much between the two models.

\section{Model application}

Equation (14) and the NRC guidelines [14] were used to predict $\mathrm{N}$ and $\mathrm{P}$ excretion and retention for all dairy cows in the data set $(n=144)$. Table 6 shows the average prediction of $N$ 


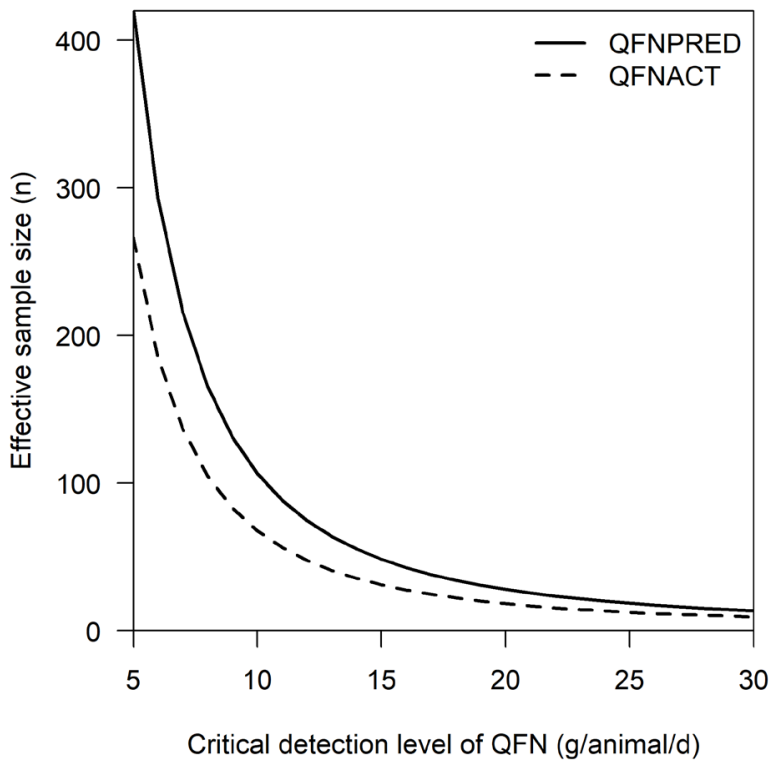

Figure 2. The relationship between effective sample size of dairy cows ( $\mathrm{n}$ ) and a specific difference of $Q_{F N}(g / a n i m a l / d)$ in two alternative models $\left(Q_{\text {FNPRED, }} R^{2}=\right.$ 0.63 and $\left.Q_{\text {FNACT }} R^{2}=1\right)$. The solid line indicates the $Q_{\text {FNPRED }}$ and the dashed line indicates the $Q_{\mathrm{FNACT}} \mathrm{Q}_{\mathrm{FN}}$, quantity of faecal $\mathrm{N} ; \mathrm{Q}_{\mathrm{FNPRED}}$, predicted quantity of faecal $\mathrm{N} ; \mathrm{Q}_{\mathrm{FNACT}}$, actual quantity of faecal $\mathrm{N}$.

and $\mathrm{P}$ excreted and retained (g/animal/d) per animal class. The average $\mathrm{Q}_{\mathrm{FN}}$ was higher for lactating cows (107 g/ani$\mathrm{mal} / \mathrm{d}, 38 \%$ of TNI) than for dry cows $(83 \mathrm{~g} / \mathrm{animal} / \mathrm{d}, 39 \%$ of TNI) and young cows (57 g/animal/d, 39\% of TNI). Similarly, the average $\mathrm{Q}_{\mathrm{UN}}$ was higher for lactating cows $(111 \mathrm{~g} /$ animal $/ \mathrm{d}, 40 \%$ of TNI), than for dry cows $(99 \mathrm{~g} / \mathrm{animal} / \mathrm{d}$, $47 \%$ of TNI) and young cows ( $60 \mathrm{~g} / \mathrm{animal} / \mathrm{d}, 41 \%$ of TNI). Overall, the average $\mathrm{Q}_{\mathrm{FN}}$ was $96 \mathrm{~g} / \mathrm{animal} / \mathrm{d}$ and $\mathrm{Q}_{\mathrm{UN}}$ was 101 $\mathrm{g} /$ animal $/ \mathrm{d}$. The average $\mathrm{N}_{\text {Ret }}$ was $63 \mathrm{~g} / \mathrm{animal} / \mathrm{d}$ for lactating cows ( $22 \%$ of TNI), $29 \mathrm{~g} / \mathrm{animal} / \mathrm{d}$ for dry cows ( $14 \%$ of TNI), and $30 \mathrm{~g} / \mathrm{animal} / \mathrm{d}$ for young cows ( $20 \%$ of TNI). In the case of Indonesian smallholder dairy farms, on average $22 \%$ of TNI was retained and the remaining $78 \%$ of TNI was found in manure, with $38 \%$ in the faeces and $40 \%$ in the urine.

The average $\mathrm{Q}_{\mathrm{FP}}$ was $63 \mathrm{~g} / \mathrm{animal} / \mathrm{d}$ (89\% of PI) for lactat-

Table 6. Predicted $\mathrm{N}$ and $\mathrm{P}$ excreted and retained (mean $\pm \mathrm{SE}$ ) in lactating cows, dry cows and young cows on 30 smallholder dairy farmers in Lembang, West Java, Indonesia

\begin{tabular}{lcccc}
\hline $\begin{array}{r}\text { Parameters } \\
\text { estimate }\end{array}$ & $\begin{array}{c}\text { Lactating } \\
\text { cows }\end{array}$ & $\begin{array}{c}\text { Dry } \\
\text { cows }\end{array}$ & $\begin{array}{c}\text { Young } \\
\text { cows }\end{array}$ & Average \\
\hline $\mathrm{Q}_{\mathrm{FN}}$ & $107 \pm 2.5$ & $83 \pm 8.2$ & $57 \pm 4.3$ & $96 \pm 2.6$ \\
$\mathrm{Q}_{\mathrm{UN}}$ & $111 \pm 5.3$ & $99 \pm 11.9$ & $60 \pm 6.0$ & $101 \pm 4.5$ \\
$\mathrm{Q}_{\mathrm{TN}}$ & $218 \pm 7.8$ & $182 \pm 20.1$ & $117 \pm 10.3$ & $197 \pm 7.1$ \\
$\mathrm{~N}_{\text {Ret }}$ & $63 \pm 1.9$ & $29 \pm 0.02$ & $30 \pm 2.3$ & $54 \pm 1.80$ \\
$\mathrm{Q}_{\mathrm{FP}}$ & $63 \pm 5.6$ & $47 \pm 8.4$ & $32 \pm 4.2$ & $56 \pm 2.5$ \\
$\mathrm{P}_{\text {Ret }}$ & $8 \pm 0.1$ & $5 \pm 0.1$ & $5 \pm 0.05$ & $7 \pm 0.2$ \\
\hline
\end{tabular}

$\mathrm{SE}$, standard error; $\mathrm{Q}_{\mathrm{FN}}$, quantity of faecal $\mathrm{N} ; \mathrm{Q}_{\mathrm{UN}}$ quantity of urinary $\mathrm{N} ; \mathrm{Q}_{\mathrm{TN}}$ quantity of total $\mathrm{N}$; $\mathrm{N}_{\text {Ret }}$ retained $\mathrm{N}$; QFP, quantity of faecal $\mathrm{P} ; \mathrm{P}_{\text {Rett }}$ retained $\mathrm{P}$. ing cows, $47 \mathrm{~g} /$ animal/d (90\% of PI) for dry cows, and $32 \mathrm{~g} /$ animal/d ( $86 \%$ of PI) for young cows. The average $\mathrm{P}_{\text {Ret }}$ was 8 $\mathrm{g} / \mathrm{animal} / \mathrm{d}(11 \%$ of PI) for lactating cows, $5 \mathrm{~g} /$ animal $/ \mathrm{d}(10 \%$ of PI) for dry cows, and $5 \mathrm{~g} / \mathrm{animal} / \mathrm{d}$ (14\% of PI) for young cows. In the case of Indonesian smallholder dairy farms, on average $12 \%$ of PI was retained and $88 \%$ of PI was found in the manure. Average daily $\mathrm{N}$ and $\mathrm{P}$ excretion per farm (three lactating, one dry and one young cow) is approximately 947 $\mathrm{g} \mathrm{N}$ and $268 \mathrm{~g} \mathrm{P}$.

\section{DISCUSSION}

Since it is very difficult to sample manure and assess manure quantity at dairy farms we calibrated and evaluated the $\mathrm{Q}_{\mathrm{FN}}$ model, and subsequently predicted $\mathrm{Q}_{\mathrm{FN}}, \mathrm{Q}_{\mathrm{UN}}$, and $\mathrm{Q}_{\mathrm{FP}}$ in our case region based on feed intake and composition, milk production and its composition, and manure composition. The Lucas equation is an important element of the $\mathrm{Q}_{\mathrm{FN}}$ model, and the model calibration for dairy cattle at the farms in the study area was essentially an evaluation of the Lucas equation for the Indonesian situation. Our estimate of true $\mathrm{N}$ digestibility equalled the standard value of $92 \%$ in the original Lucas equation, whereas our estimate of metabolic faecal $\mathrm{N}$ was $-0.60 \mathrm{~g} / 100 \mathrm{~g}$ DMI, with the standard value being -0.61 $\mathrm{g} / 100 \mathrm{~g}$ DMI. Our estimates of true N digestibility and metabolic faecal N, furthermore, were similar to those reported in literature [12]. Hence, the standard Lucas equation for $\mathrm{N}$ seems to apply under a wide array of conditions, including Indonesian smallholder dairy farms [29]. Consequently, the $\mathrm{Q}_{\mathrm{FN}}$ model presented in this study can be applied under very different circumstances, and the standard values from the Lucas equation can likely be used.

To test the robustness of model, we applied a calibration/ evaluation approach instead of using a sensitivity analysis. Results of the model evaluation showed that the $\mathrm{Q}_{\mathrm{FNPRED}}$ model had a relatively high relative MAE (17\%) and relative RMSE (22\%). In literature [30] errors of $20 \%$ were found during the quantification of potential and feed-limited growth of three beef cattle breeds by a generic model which was followed by a model evaluation on independent experimental data. This error is comparable to our findings. The systematic errors (bias error and slope error) were limited and the major source of error was the random error (79\%). The relatively high error could in part be attributed to the fact that some model parameters such as DDM had to be derived from literature $[17,18]$. The specified information of DDM for many feed types, for example the roughage, is limited for the Indonesian situation, whereas the variation in DDM quality of roughage among farmers is expected to be high. In addition, the $\mathrm{Q}_{\mathrm{FNACT}}$ that was used as actual value for model evaluation and for the estimation of the effective sample size was considered without error. In reality, the $\mathrm{Q}_{\mathrm{FNACT}}$ also has an estimation error be- 
cause of errors related to sampling, to laboratory analysis and to the DDM values used to estimate $\mathrm{Q}_{\mathrm{FNACT}}$. Hence, the MAE and RMSE of $\mathrm{Q}_{\mathrm{FNPRED}}$ when evaluated against a real direct assessment (full collection of faecal and urinary excretion separately and compositional analysis of each fraction) will likely be higher than when compared to the $\mathrm{Q}_{\mathrm{FNACT}}$ in the present study.

We used the NRC guideline to estimate the nutrient requirements. In Indonesia, it is widely used because of the absence of a national system to estimate dairy cattle feed requirements. Nevertheless, since the cattle were high grade Holstein Friesian cows, we believe that most NRC predictions are applicable to the breed in Indonesia, and because the weather conditions in the research area are relatively mild, they also apply to the climatic conditions.

We selected the farms randomly and we collected feed samples from each farm, so we assume the farm and feed samples represented the actual situation. The variation in composition of agro-industrial by-products and concentrate was low with limited difference between dry and rainy season because they were produced by agro-industries which use standardized processes, hence delivering standard quality, even of the by-products they sell. In addition, the concentrate was produced by the dairy cooperative with the aim to deliver standardized quality to the members of the cooperative. The roughage differed only slightly between seasons [31]. Since the Lembang area is small, conditions for all farmers are similar. Hence, variation in composition between diets and within feeds was small in the Lembang area.

The average predicted $\mathrm{Q}_{\mathrm{FN}}$ was lower $(96 \mathrm{~g} / \mathrm{animal} / \mathrm{d})$ than some values reported in literature (147 to $242 \mathrm{~g} / \mathrm{animal} / \mathrm{d}$ ) $[5,6,8]$. The difference between our estimate and these reported values could be due to the lower DMI and NI in our study. To verify this conclusion, we inserted the DMI and NI values from literature $[5,6,8]$ into our $\mathrm{Q}_{\mathrm{FN}}$ model, and the result showed that the relative deviation of predicted $\mathrm{Q}_{\mathrm{FN}}$ values from the values reported in previous studies varied from $-15 \%$ to $19 \%$.

We calculated nutrient use inefficiency for nitrogen $\left(\mathrm{NUI}_{\mathrm{N}}\right)$ by expressing excreted $\mathrm{N}$ as percentage of NI. In our study, this $\mathrm{NUI}_{\mathrm{N}}$ was $78 \%$ meaning that $78 \%$ of $\mathrm{N}$ intake ended up in manure, and only $22 \%$ in milk and meat. The $\mathrm{NUI}_{\mathrm{N}}$ in literature $[5,8,32]$ was lower than the one found by us i.e. $70 \%$ to $72 \%$. This could mean two things: either $\mathrm{N}$ losses via manure were higher from the cattle in our study caused by a low efficiency of $\mathrm{N}$ utilization in the animal which could be caused by limitation by other nutrients, by the genetic potential of the animals or by health-related factors [30] or it could just be that too much $\mathrm{N}$ was offered through the diets. These reasons imply that improving feeding management for example through nutritionally balanced rations [33], adjustment of the dairy genetics to the production potential at the present feed base and animal health care may potentially reduce nutrient excretion.

Some mathematic models to predict $\mathrm{N}$ and $\mathrm{P}$ excretion of dairy cows are developed based on input-output relations from dairy farms in a specific context. Although such models are compelling because they only require limited data to predict the $\mathrm{N}$ and $\mathrm{P}$ excretion, they may fail when applied in systems different from the one for which they were created [34]. Applying such existing models to the case of smallholder dairy farms in Indonesia, therefore, may lead to over or under estimation of $\mathrm{N}$ and $\mathrm{P}$ excretion because of differences in feed input (lower feed intake) and animal characteristics (lower milk production and body weight). Therefore, a generic model is proposed. The generic model in this study described the process of $\mathrm{N}$ digestion and $\mathrm{N}$ utilisation for maintenance, growth and production based on well-established methods generally applied in animal nutrition (Lucas equation and NRC). Additionally, this generic model is calibrated and evaluated, and the model evaluation showed that the model can be used to estimate faecal $\mathrm{N}$ at smallholder dairy farms in Indonesia.

\section{CONCLUSION}

We developed, calibrated and evaluated a generic model to predict $\mathrm{Q}_{\mathrm{FN}}$ from dairy cattle on smallholder farms in Indonesia using readily available farm data, and applied this model, in combination with existing guidelines of the National Research Council, to predict $\mathrm{N}$ and $\mathrm{P}$ excretion in faeces and urine for 144 dairy cows on 30 farms. In conclusion, the proposed models can be used with reasonable accuracy to predict $\mathrm{N}$ and $\mathrm{P}$ excretion of dairy cattle on smallholder farms in Indonesia using readily available farm data. The model can be used as a basic tool to improve manure management and to reduce nutrient losses in Indonesian smallholder dairy farms.

\section{CONFLICT OF INTEREST}

We certify that there is no conflict of interest with any financial organization regarding the material discussed in the manuscript.

\section{ACKNOWLEDGMENTS}

The Indonesian Endowment Fund for Education (LPDP) is acknowledged for a doctoral scholarship to the first author. The dairy cooperative/Koperasi Peternakan Sapi Perah Bandung Utara (KPSBU) Jawa Barat Indonesia is acknowledged for supporting data collection. This work was implemented as part of the CGIAR Research Program on Climate Change, Agriculture and Food Security (CCAFS) with funding sup- 
port from the government of The Netherlands. CCAFS is carried out with support from CGIAR Fund Donors and through bilateral funding agreements. For details please visit https://ccafs.cgiar.org/donors. The views expressed in this document cannot be taken to reflect the official opinions of these organizations.

\section{REFERENCES}

1. Kementrian Pertanian. Indonesian livestock and animal health statistics. Jakarta, Indonesia: Kementrian Pertanian Republik Indonesia; 2018.

2. Biagini D, Lazzaroni C. Eutrophication risk arising from intensive dairy cattle rearing systems and assessment of the potential effect of mitigation strategies. Agric Ecosyst Environ 2018;266:76-83. https://doi.org/10.1016/j.agee.2018.07.026

3. De Vries M, Wouters APB, Vellinga T. Environmental impacts of dairy farming in lembang, west java. Wageningen, the Netherlands: CGIAR Research Program on Climate Change, Agriculture and Food Security (CCAFS); 2017. Working Paper No: 221.

4. Laubach J, Taghizadeh-Toosi A, Gibbs SJ, Sherlock RR, Kelliher FM, Grover SPP. Ammonia emissions from cattle urine and dung excreted on pasture. Biogeosciences 2013;10:327-38. https://doi.org/10.5194/bg-10-327-2013

5. Knowlton KF, Wilkerson VA, Casper DP, Mertens DR. Manure nutrient excretion by Jersey and Holstein cows. J Dairy Sci 2010;93:407-12. https://doi.org/10.3168/jds.2009-2617

6. Qu QB, Yang P, Zhao R, et al. Prediction of fecal nitrogen and phosphorus excretion for Chinese Holstein lactating dairy cows. J Anim Sci 2017;95:3487-96. https://doi.org/10.2527/ jas.2017.1432

7. Gérard-Marchant P, Walter MT, Steenhuis TS. Simple models for phosphorus loss from manure during rainfall. J Environ Qual 2015;34:872-6. https://doi.org/10.2134/jeq2003.0097

8. Nennich TD, Harrison JH, Van Wieringen LM, et al. Prediction of manure and nutrient excretion from dairy cattle. J Dairy Sci 2005;88:3721-33. https://doi.org/10.3168/jds.S00220302(05)73058-7

9. Weiss WP, St-Pierre NR, Willett LB. Factors affecting manure output on dairy farms. In: Tri-State Dairy Nutrition Conference 2007; 2007 April 24-25; Ft. Wayne, IN, USA.

10. Weisbjerg MR, Hvelplund T, Søegaard K. Prediction of digestibility of neutral detergent solubles using the Lucas principle. J Anim Feed Sci 2004;13(Suppl 1):239-42. https://doi.org/10. 22358/jafs/73849/2004

11.Lucas HL. Stochastic elements in biological models; their sources and significance. In: Stochastic Models in Medicine and Biology. Madison, WI, USA: University Wisconsin Press; 1964.

12. Van Soest PJ. Nutritional ecology of the ruminant (2nd Ed). Ithaca, NY, USA: Cornell Univ Press; 1994
13. Krizsan SJ, Alamouti HM, Rinne M, Huhtanen P. Indigestible neutral detergent fibre in predictions of grass and red clover silage digestibility. Grass Forage Sci 2014;69:266-75. https://doi.org/10.1111/gfs.12029

14. NRC. Nutrient requirements of dairy cattle. Seventh revised edition. Washington, DC, USA: The National Academies Press; 2001.

15. Alvarez-Fuentes G, Appuhamy JADRN, Kebreab E. Prediction of phosphorus output in manure and milk by lactating dairy cows. J Dairy Sci 2016;99:771-82. https://doi.org/10.3168/jds. 2015-10092

16. Valk H, Šebek LBJ, Beynen AC. Influence of phosphorus intake on excretion and blood plasma and saliva concentrations of phosphorus in dairy cows. J Dairy Sci 2002;85:2642-9. https:// doi.org/10.3168/jds.S0022-0302(02)74349-X

17. Feedipedia: Animal Feed Resources Information System [Internet]. INRA CIRAD AFZ and FAO; 2012-2019 [cited 2018 Dec]. Available from: https://www.feedipedia.org/

18. Tatra AJ, Abdullah L, Despal. Effective fibre availability and tannin existence in Lembang traditional dairy farms ration and their influence on milk production and quality [master's thesis]. Bogor, Indonesia: Bogor Agricultural University; 2015

19. Kusuma SB, Ngadiyono N, Sumadi S. The correlation of body measurements and weights of ongole crossbred (po) cattle in Kebumen Regency. In: Proceedings of the 7th International Seminar on Tropical Animal Production 2017; 2017 Sept 12-14; Yogyakarta, Indonesia

20. Aprily NU, Sambodho P, Harjanti DW. Calving evaluation of dairy cattle in balai besar pembibitan ternak unggul dan hijauan pakan ternak baturraden. Jurnal Peternakan Indonesia 2016;18:36-43.

21.Salman LB, Sumantri C, Noor RR, Saefuddin A, Talib C. Growth curve of Frisian- Holstein birth to first mating age using logistic mathematical model. Informatika Pertanian 2014;23:73-84.

22. Bibby J, Toutenburg H. Prediction and improved estimation in linear models. London, UK: John Wiley \& Sons; 1977.

23. Cohen J. Statistical power analysis for the behavioural sciences 2nd Ed. New York, USA: Lawrence Erlbaum Associates Publishers; 1998.

24. Badan Standarisasi Nasional. Indonesian national standard for concentrate feed of dairy cattle [internet]. Jakarta, Indonesia: Badan Standarisasi Nasional; c2009 [cited 2018 Dec]. Available from: https://bsn.go.id/

25. Badan Standarisasi Nasional. Indonesian national standard for fresh milk [internet]. Jakarta, Indonesia: Badan Standarisasi Nasional; c1998 [cited 2018 Dec]. Available from: https://bsn.go.id/

26. Wattiaux MA. Protein metabolism in dairy cows. In: Technical dairy guide nutrition. 2nd ed. Madison, WI, USA: The Babcock Institute for International Dairy Research and Development, The University of Wisconsin; 1998. 
27. Van Vliet PCJ, Reijs JW, Bloem J, Dijkstra J, De Goede RGM. Effects of cow diet on the microbial community and organic matter and nitrogen content of feces. J Dairy Sci 2007;90: 5146-58. https://doi.org/10.3168/jds.2007-0065

28. Wang C, Liu Z, Wang D, Liu J, Liu H, Wu Z. Effect of dietary phosphorus content on milk production and phosphorus excretion in dairy cows. J Anim Sci Biotechnol 2014;5:23. https://doi.org/10.1186/2049-1891-5-23

29. Oosting SJ, Vlemmix PJ, Van Bruchem J. Effect of ammonia treatment of wheat straw with or without supplementation of potato protein on intake, digestion and kinetics of comminution, rumen degradation and passage in steers. $\mathrm{Br} \mathrm{J}$ Nutr 1994;72:147-65. https://doi.org/10.1079/BJN19940016

30. Van der Linden A, Van de Ven GWJ, Oosting SJ, Van Ittersum MK, De Boer IJM. LiGAPS-Beef, a mechanistic model to explore potential and feed-limited beef production 3: Model evaluation. Animal 2019;13:868-78. https://doi.org/10.1017/ S1751731118002641
31. Haegele MT, Arjharn W. The effects of cultivation methods and planting season on biomass yield of Napier grass (Pennisetum purpureum Schumach.) under rainfed conditions in the northeast region of Thailand. Field Crops Res 2017;214: 359-64. https://doi.org/10.1016/j.fcr.2017.09.027

32. Jiao HP, Yan T, McDowell DA. Prediction of manure nitrogen and organic matter excretion for young holstein cattle fed on grass silage-based diets. J Anim Sci 2014;92:3042-52. https:// doi.org/10.2527/jas.2013-7552

33. Garg MR, Sherasia PL, Phondba BT, Makkar HPS. Greenhouse gas emission intensity based on lifetime milk production of dairy animals, as affected by ration-balancing program. Anim Prod Sci 2018;58:1027-42. https://doi.org/10.1071/ AN15586

34. Duarte CM, Amthor JS, De Angelis DL, et al. The limits to models in ecology. In: Models in ecosystem science. Princeton, NJ, USA: Princeton University Press; 2003. pp. 437-51. 